\title{
PENDEKATAN METODE DESAIN BERBASIS PERILAKU DALAM DESAIN PROYEK POJOK HIJAU CITRA 6
}

\author{
Singgih Pratama ${ }^{1)}$, Priscilla Epifania ${ }^{2)}$ \\ 1)Program Studi S1 Arsitektur, Fakultas Teknik, Universitas Tarumanagara, singgih38@gmail.com \\ 2)Program Studi S1 Arsitektur, Fakultas Teknik, Universitas Tarumanagara, priscillae@ft.untar.ac.id
}

\begin{abstract}
Abstrak
Tempat ketiga atau third place merupakan salah satu ruang sosial yang inklusif bagi masyarakat sekitarnya dan memiliki karakteristik sesuai kawasannya. Dalam pembentukan tempat ketiga, terdapat beberapa faktor yang dapat membentuk tempat tersebut menjadi suatu kawasan yang inklusif dan komunal, diantaranya; konfigurasi, konektifitas, dan integrasi ruang. Salah satu hal penting yang perlu diperhatikan adalah penciptaan ruang di kawasan tersebut yang mengacu pada aktivitas masyarakat di sekitarnya. Penelitian ini bertujuan untuk memberikan suatu gagasan akan suatu metode desain berbasis perilaku dengan tahapan sebagai berikut, antara lain: pertama, studi literatur terkait arsitektur keseharian masyarakat di kawasan sekitar, space syntax, dan tempat ketiga yang sudah ada di daerah tersebut; kedua, melakukan observasi tapak serta mendokumentasikan berbagai macam aktivitas yang terjadi di tempat tersebut; ketiga, melakukan penyusunan program ruang yang selanjutnya dilakukan proses komputasi untuk menghasilkan alternatif desain pada peletakan organisasi ruang; keempat, membuat skenario ruang dengan hasil observasi aktvitas yang telah dilakukan kemudian diolah untuk dikombinasikan dengan hasil komputasi desain. Dengan melakukan pendataan aktivitas ruang keseharianserta peletakan ruang dengan metode komputasi,ruang yang terbentuk dapat memberikan karakterisitik kawasannya dikarenakan perilaku keseharian mereka mempengaruhi ruang serta aktivitas yang terjadi. Dengan melakukan metode ini diharapakan tempat ketiga pada kawasan menjadi tidak asing bagi para penggunanya dikarenakan ruang tersebut memiliki tanda-tanda yang dikenali penggunanya.
\end{abstract}

Kata kunci: arsitektur; arsitektur keseharian; perilaku; space syntax; tempat ketiga

\begin{abstract}
Third place as an inclusive social space for people has characteristics that represent their place. In the making of a third place, there are some factors that make the place feels inclusive and communal, which is configuration, connectivity, and integrated spaces. Other things that crucial for the creation of form is the people's activities of its place. This research is made to present a design using behaviour methods. The methods that researcher used are: conducting some literature studies about everydayness, space syntax, and third place; second, do an observation on site then record the activities that happen on the site; third, list all the programs then use computation to make design layout alternatives; fourth, using the observations to make a scenario then mix it with computation design. By recording the activities of spaces and organizing the spaces with computation, it is expected the spaces that are made aren't strange to its user, and the spaces also have a character from the community itself.
\end{abstract}

Keywords: architecture; behaviour; everyday architecture; space syntax; third place 


\section{PENDAHULUAN}

\section{Latar Belakang}

Ruang pada kota memiliki peran penting bagi masyarakatnya sebagai wadah untuk bersosialisasi, berkumpul, dan beraktivitas. Akan tetapi, Jakarta minim dengan ruang kota berbasis sosial, di mana ruang tersebut bersifat tidak terbuka bagi komunitas masyarakat tertentu. Menurut Oldenburg (1989) ruang yang bersifat terbuka dan inklusif menjadi tempat ketiga bagi masyarakatnya, tempat tersebut merupakan tempat persinggahan sementara untuk bersosialisasi sebelum melakukan pekerjaan atau pulang menuju ke rumah.

Dalam membentuk sebuah tempat ketiga diperlukan karakteristik kawasan serta kemampuan ruang dalam memenuhi kebutuhan pengguna sekitarnya. Tempat ini menjadi tempat yang melayani dan dilayani oleh masyarakatnya sehingga membentuk sesuatu yang tidak asing secara ruang maupun aktivitas. Citra 6 merupakan sebuah daerah yang berada di perbatasan Tegal Alur dan Pegadungan, Jakarta Barat. Tempat tersebut menjadi tempat tinggal bagi pekerja maupun pelajar yang bekerja di Kota Jakarta. Kawasan ini dikenal sebagai tempat kuliner bagi orang yang tinggal di sekitarnya kemudian terdapat waduk yang menjadi atraksi bagi orang-orang yang melakukan olahraga saat pagi dan sore hari. Untuk membentuk sesuatu yang tidak asing bagi masyarakatnya, diperlukan pendekatan desain yang sesuai karakteristik ruang dan perilaku masyarakatnya. Oleh karena itu, diperlukan metode desain yang berbasis perilaku keseharian masyarakat dan peletakan ruang yang memaksimalkan nilai komunal.

\section{Rumusan Permasalahan}

Karakteristik seperti apa yang terbentuk dari perilaku keseharian hidup masyarakat pada kawasan Citra 6 dan pengaruh ruang terhadap aktivitas keseharian mereka.

\section{Tujuan}

Penelitian ini bertujuan untuk mengaplikasikan metode arsitektur berbasis perilaku pada sebuah kawasan terhadap bentuk perancangan.

\section{KAJIAN LITERATUR}

\section{Tempat Ketiga}

Oldenburg (1989:41-62) mengatakan bahwa manusia memiliki tempat ketiga yang disebut sebagai Third Place. Tempat tersebut merupakan tempat di mana masyarakat dapat berinteraksi sosial maupun bertukar informasi.

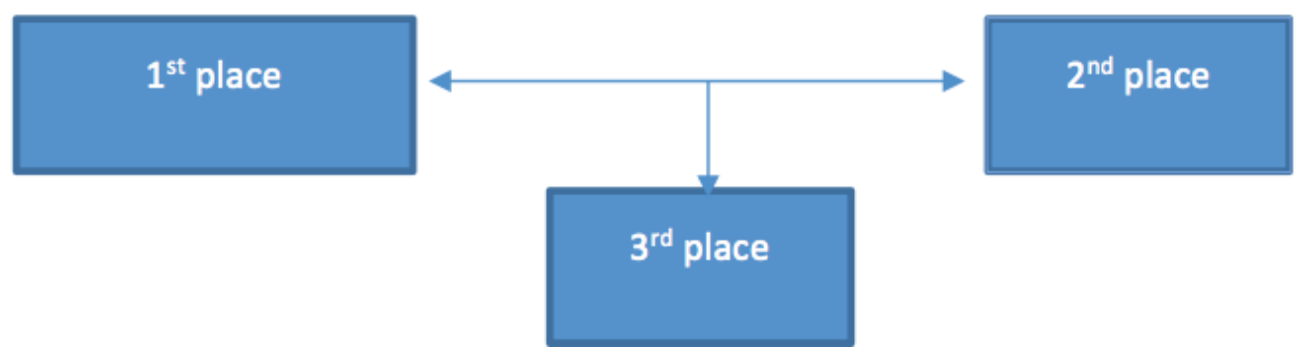

Gambar 1. Diagram skema keberadaan third place

Sumber: olahan pribadi, 2020

Oldenburg mengatakan bahwa home merupakan first place dan tempat kerja merupakan second place. Menurut dia, third place memiliki karakteristik tersendiri yang membedakan tempat tersebut dari first dan second place. Terbentuknya third place memberikan ruang yang dapat diakses oleh semua orang tanpa adanya kesenjangan sosial. 
Menurut Sutanto (2020:169) pada Peta Metode Desain, 'tempat ketiga' merupakan sebuah lingkungan sosial yang inklusif. Tempat ketiga memiliki karakteristik terbuka dan kontekstual sehingga mencerminkan sifat atau karakteristik lokal pada suatu tempat. Sifat lainnya berupa ruang sosial yang mempunyai fleksibilitas yang tinggi. Fleksibilitas tersebut tercermin pada cara pengguna ruang mengekspresikan emosinya secara bebas dalam program yang beragam dapat berupa sebuah cara bagaimana pengguna ruang dapat mengekspresikan emosi mereka secara bebas serta program yang beragam.

\section{Space Syntax}

Ruang pada kota ataupun interior terbentuk karena kekuatan psikologi atau sosial sekitar sehingga dapat disebut sebagai asumsi yang berkelanjutan, di mana terbentuk batasanbatasan ruang sehingga menciptakan rangkaian kejadian yang terpisah. Asumsi ini mempengaruhi setiap bangunan, di mana orang baru selalu masuk dan keluar bangunan sehingga mereka mempunyai alasan yang kuat untuk melewati ruang tersebut walau tidak mempunyai kuasa pada ruangan di bangunan tersebut. Hal ini membatasi dunia orang asing secara bentuk ruang bangunan, sebaliknya bangunan tersebut juga membatasi dunia pengguna regular. Perancang bangunan tersebut sadar akan peraturan lokal sehingga menggunakan kesadaran tersebut sebagai batasan untuk dunia sosial. (Hillier \& Hanson, 1988: 144-146)

Hillier (1997) menjelaskan bahwa sebuah konfigurasi ruang memiliki dampak bagi pengguna ruang tersebut. Bill menjelaskan sebuah ruang memiliki tiga poin yang mempengaruhi perilaku mereka dalam sebuah ruang yaitu.

a. Konektivitas:

Apabila kita berada di sebuah ruangan, kita akan melihat berapa banyak ruangan bertetanggan yang terkoneksi dengan ruang yang kita huni.

b. Integrasi:

Berbeda dengan konektivitas, integrasi ruang merupakan sebuah sistem konfigurasi konektivitas ruang. Terbentuknya konektivitas antar ruang yang baik menjadi tanda dari sistem ruang yang baik

c. Visibilitas:

Visibilitas dilambangkan dengan garis axial pada denah dua dimensi. Semakin banyak garis pada sirkulasi sebuah denah kota atau bangunan, maka ruang tersebut menjadi strategis. Segi kultural dan sosial dapat terpengerahi melalui visibilitas konfigurasi ruang.

Dalam buku Basic Design Method mengatakan bahwa space syntax yang dihasilkan oleh Bill Hillier dan Hanson merupakan sebuah metode yang menganalisis hubungan ruang dengan manusianya tanpa nilai kultural serta estetika. Hasil analisis space syntax memprediksi perilaku manusia pada bangunan dan ruang-ruang kota. Metode ini tidak memberikan sebuah bentuk tetapi memberikan penilaian dari efek sebuah konfigurasi ruang sehingga menghasilkan beberapa alternatif desain (Jormakka et al., 2007, p. 45). Grafik dan diagram bubble digunakan sebagai alat pengaturan ruang sehingga mempermudah komunikasi tentang ide antara perancang dan komputasi. Alat ini menggunakan analisis konfigurasi peletakan tata ruang menggunakan teori space syntax (Nourian et al., 2013)

\section{Arsitektur Keseharian}

De Certeau (1984:77) mengatakan bahwa manusia menciptakan sebuah narasi terhadap ruang yang dia rasakan. Narasi yang baik memerlukan beberapa dimensi agar terbentuk narasi yang baik salah satunya adalah memori. Manusia sebagai pembuat narasi memiliki beberapa cara membentuk narasi tersebut tersebut antara lain:

a. Alterasi 
Memori yang praktikal akan diatur oleh beberepa jenis aktivitas yang mengalami alterasi. Bukan disebabkan oleh pengaruh eksternal tetapi oleh tulisan atau memori yang diingat kembali dalam bentuk penggalan. Contohnya ketika Anda duduk di pinggir danau dan merasa sejuk. Memori tersebut merekam berdasarkan kondisi lingkungan yang terjadi.

b. Tunggal

Dalam sebuah memori diperlukan respon tunggal, di mana sebuah aksi atau perkataan maupun tempat menjadi sebuah detail dalam memori tersebut.

c. Mobilitas

Detail yang terakhir merupakan pergerakan, penggalan-penggalan memori menjadi sebuah kesatuan karena digerakkan dalam memori manusia. Penggalan-penggalan tersebut dapat menjadi pengingat kembali kejadian yang sudah dilakukan sehingga dilakukan aksi yang baru

Berbeda dengan pendekatan Lefebvre (1991:33), di mana pendekatan arsitektur keseharian bersifat kolektif serta membebaskan manusia dari segi aktivitas. Menurut Lefebvre, ruang sosial memiliki sebuah konseptual tritunggal yang saling berhubungan satu sama lain yaitu.

a. Representation of space, relasi produk dan aturan saling berhubungan satu sama lain sehingga menghasilkan sebuah kode, symbol, pengetahuan dan hubungan.

b. Representational spaces, perwujudan simbol yang kompleks. Simbol terkadang memiliki makna ataupun tidak sama sekali. Simbol-simbol tersebut dihubungkan dengan kehidupan sosial sehingga dapat didefinisikan sebagai kode ruang tetapi bukan representasi sebuah ruang.

c. Spatial Practice, merupakan praktik yang menerima produksi dan reproduksi serta karakteristik setiap informasi sebuah ruang sosial. Praktik ini membuat ruang sosial terjamin keberlangsungannya dikarenkan hubungan ruang dengan objek.

Jika dilihat dari pandangan Lefebvre pada konsep tritunggal aktivitas, dia mengajak arsitek untuk melihat ruang keseharian sebagai ruang yang hidup. Dalam tritunggal Lefebvre, Sutanto memberikan penamaan lain pada konsepnya antara lain. (Sutanto, 2020, p. 151)

a. The perceived space sebagai ruang representas, arsitek atau perancang berperan melalui media gambar

b. The conceived space sebagai ruang representational, simbol- simbol yang kompleks pada kota dihadirkan dalam bentuk artefak, tugu, dan memorial park.

c. The lived space sebagai praktik spasial. Pada ruang ini, arsitek atau perancang berjuang untuk menghadirkan sebuah simbol ruang walaupun terjadi sebuah kontradiksi. Ruang praktik spasial ini terdiri dari tempat dan kelas sosial yang bersaing, yang mampu dan tidak mampu salah satunya.

\section{METODE}

Untuk melakukan penelitian ini perlu dilakukan tiga metode, antara lain :

a. Metode Pengumpulan Data

Pengumpulan data lapangan dilakukan dengan cara observasi sekitar tapak serta melakukan dokumentasi sebagai alat perancangan dalam metode arsitektur keseharian. Observasi dilakukan ketika terjadi aktivitas yang beragam

b. Metode Arsitektur Keseharian

Peneliti melakukan observasi pada kegiatan di sekitar tapak. Hasil observasi tersebut digambar ulang untuk memilah elemen pembentuk ruang serta kegiatan seperti apa yang terjadi. Hasil penggambaran tersebut dijadikan tabel kemudian dibuat skenario ruang yang diinginkan.

c. Metode Space Syntax 
Peneliti menggunakan komputasi desain untuk mendapatkan alternatif desain dengan melakukan daftar program ruang kemudian dikodekan sebagai titik atau ruang. Titik-titik tersebut dihubungkan dengan garis sebagai representasi hubungan ruang. Hubungan ini diaplikasikan dengan teori Bill Hillier (choice, integration, entropy, dan control) sehingga menghasilkan sebuah zoning ruang.

\section{DISKUSI DAN HASIL}

Dengan teori yang telah dipaparkan, peneliti melakukan space syntax terlebih dahulu untuk mendapatkan peletakan ruang yang ideal pada bangunan. Dalam mencari bentuk bangunan, dilakukan observasi untuk arsitektur keseharian kemudian dua metode tersebut digabungkan.

\section{Space Syntax}
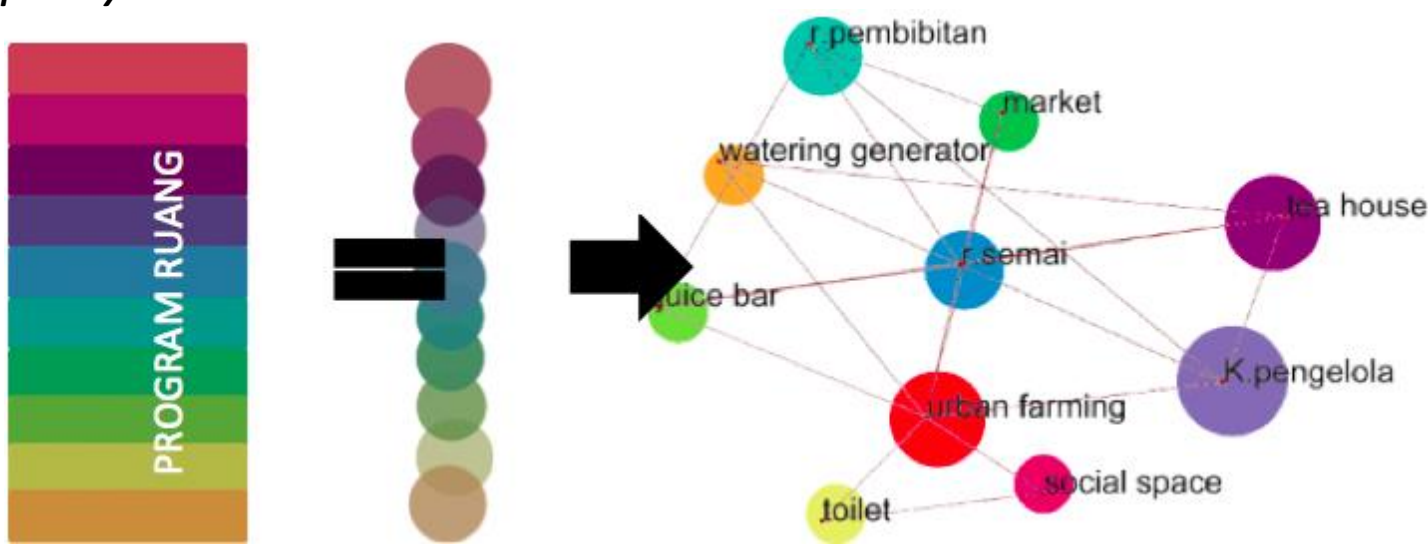

Gambar 2. Program ruang yang berkode warna(kiri) dan diagram hubungan ruang(kanan) Sumber: olahan pribadi,2020

Pada gambar di atas, program ruang yang telah dikodekan dengan warna dijadikan titik-titik seperti gambar di kanan. Titik tersebut dihubungkan dengan garis yang menunjukkan relasi antar ruang baik interaksinya maupun sebaliknya.

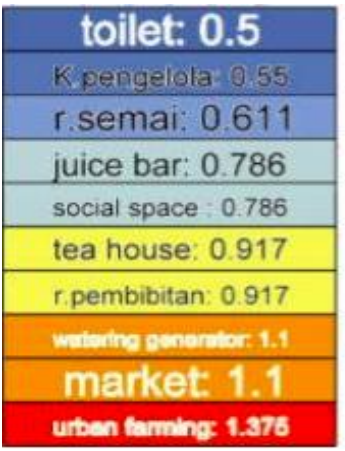

Gambar 3. (kiri ke kanan) Integration, control, entropy, dan choice Sumber: olahan pribadi, 2020

Dari hasil diagram hubungan ruang, dihasilkan empat tabel di atas, di mana setiap tabelnya memiliki peran dalam peletakan ruangnya. Pada tabel integrasi, semakin tinggi angka yang dihasilkan maka peletakan ruangnya semakin komunal dan sebaliknya. Kontrol merupakan sebuah penilaian terhadap pergerakan manusia di ruang tersebut, semakin kecil nilainya maka semakin jarang dituju. Entropi, semakin besar tinggi nilainya maka ruangan tersebut akan susah dicapai. Pilihan, semakin tinggi angkanya, maka ruangan tersebut semakin sering dilewati. 


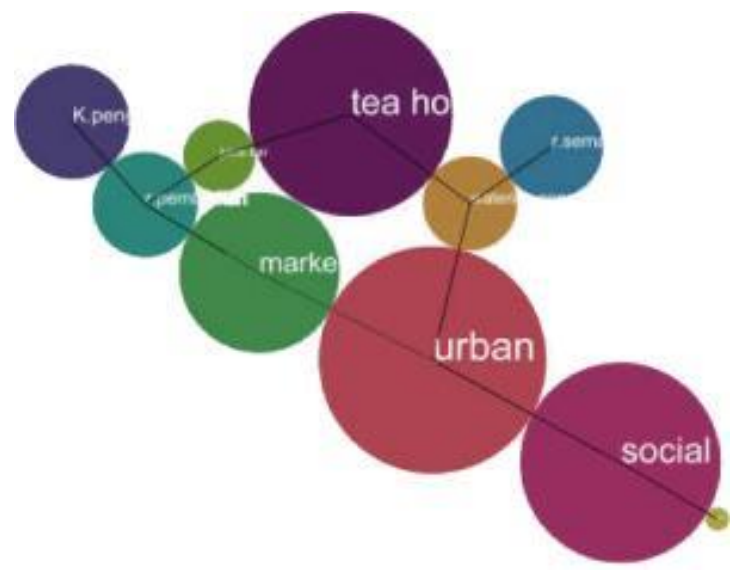

Gambar 4. Hasil aplikasi 4 poin Bill Hillier menjadi sebuah peletakan tata ruang Sumber: olahan pribadi, 2020

\section{Observasi Kegiatan Pada Tapak}

Pengumpulan data dokumentasi kegiatan pada tapak digunakan sebagai alat perancangan pada arsitektur keseharian. Data ini mempresentasikan ruang-ruang yang terjadi pada sekitar tapak serta kegiatan yang terbentuk. Dokumentasi gambar diambil menggunakan kamera.
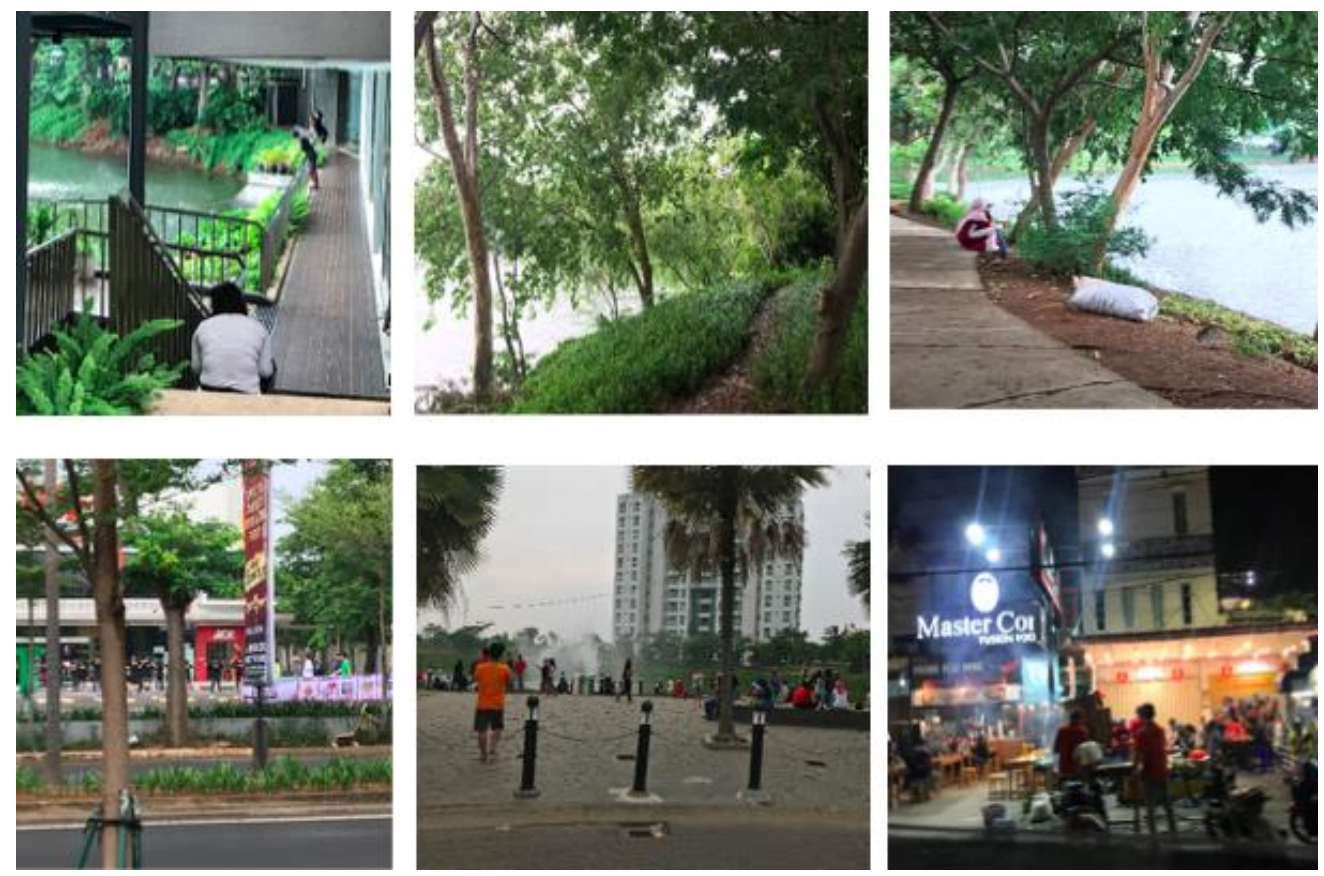

Gambar 5. Dokumentasi keadaan sekitar tapak pada waktu tertentu serta gambaran aktivitas yang terjadi

Sumber: dok. pribadi,2020

\section{Arsitektur Keseharian}

Hasil observasi kegiatan pada tapak, digambarkan ulang untuk memilah ruang yang ditangkap pengguna serta aktivitas yang terjadi dengan kondisi ruang tersebut. 
Tabel 1. Tipologi Arsitektur Keseharian
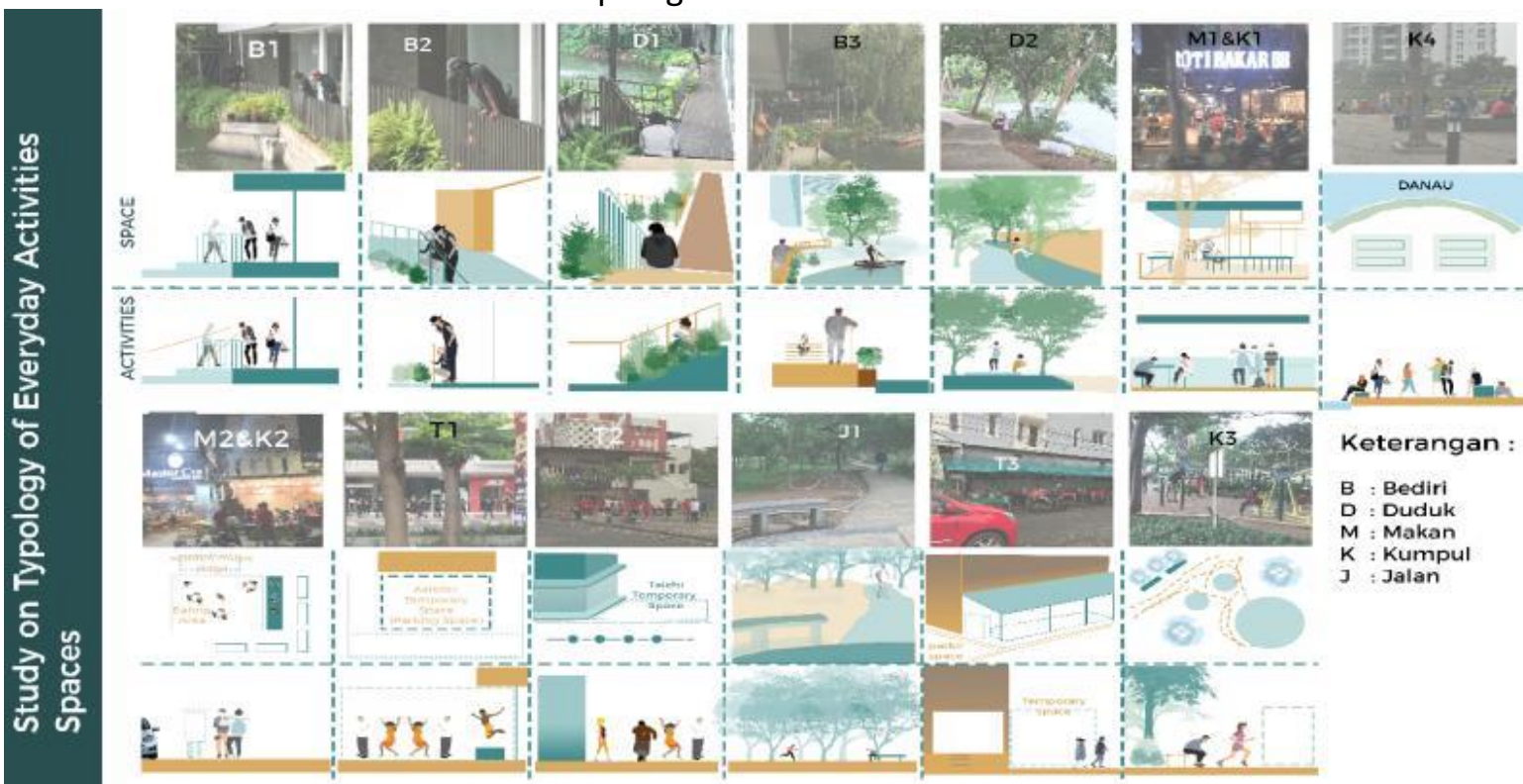

Keterangan :

B : Bediri

$\mathrm{D}$ : Duduk

$M$ : Makan

K : Kumpul

: Jalan

Sumber: Olahan pribadi,2020

Dengan melakukan penggambaran ulang, penulis dapat melihat aktivitas-aktivitas yang terjadi di sekitar tapak. Hasil penggambaran tersebut dikodekan dengan nama huruf sebagai identitas kegiatan dan kondisi ruang.

\section{Aplikasi Space Syntax dan Arsitektur Keseharian pada Bangunan}

Pengaplikasian space syntax dan arsitektur keseharian digabungkan dengan cara membuat grid pada peletakan tata ruang yang telah dihasilkan dengan space syntax. Grid ini disatukan dengan skenario kode-kode arsitektur keseharian yang telah digambar. Penggabungan dua metode ini digunakan untuk membentuk ruang pada bangunan
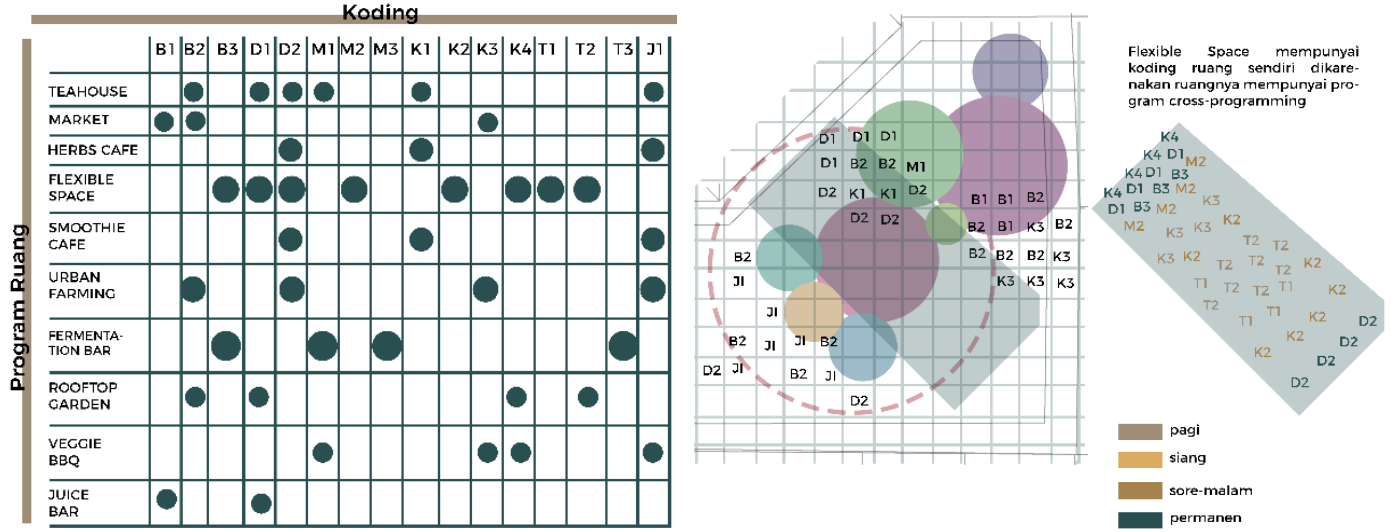

Gambar 6. (kiri) Tabel program ruang dengan skenario ruang keseharian dan (kanan) contoh peletakan skenario ruang pada grid zoning.

Sumber: olahan pribadi,2020 


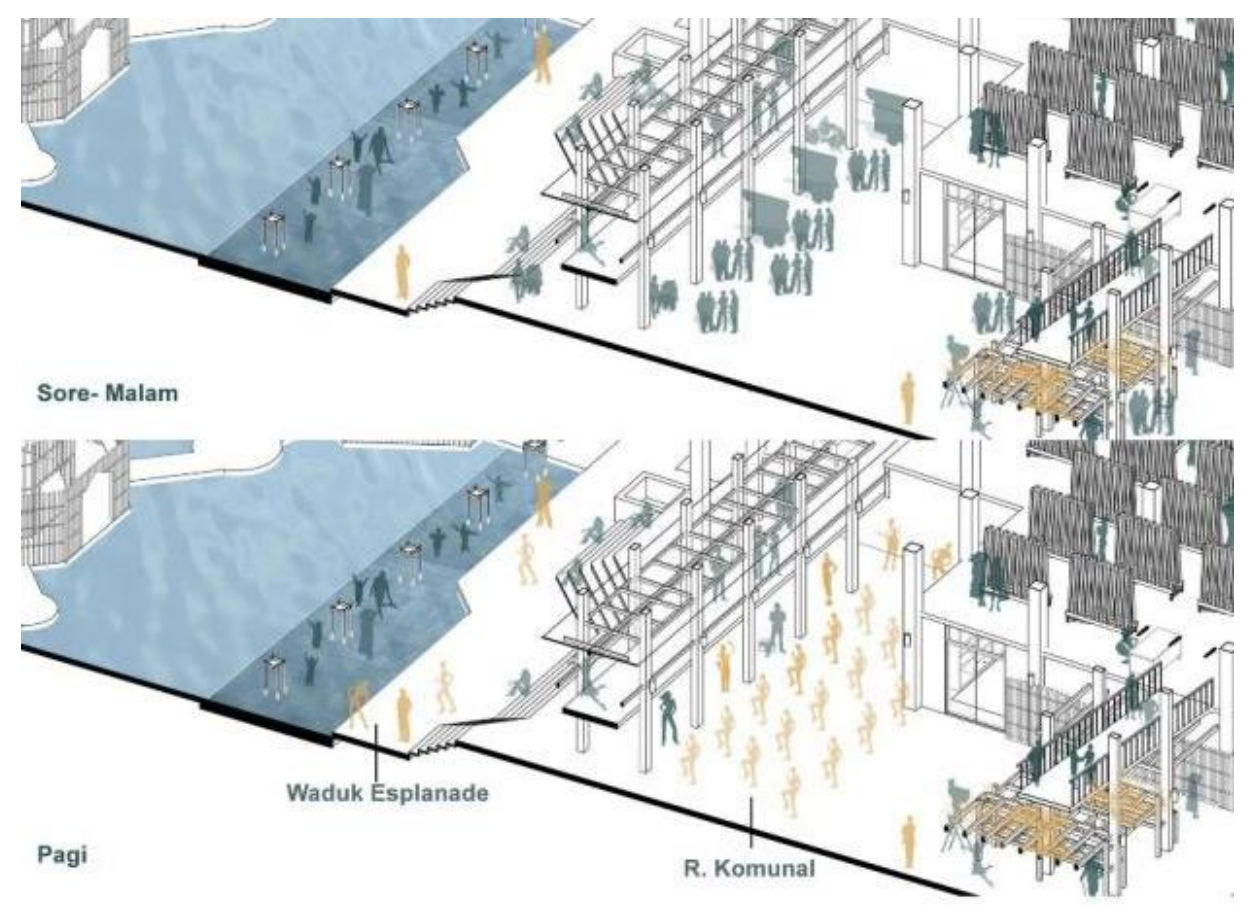

Gambar 7. Konsep skenario ruang komunal dengan skenario arsitektur keseharian Sumber: olahan pribadi, 2020

Peran arsitektur keseharian membentuk skenario ruang pada perancangan. Salah satu contohnya adalah ruang komunal, ruang tersebut memiliki ukuran yang cukup besar untuk melakukan aktivitas komunal. Skenario yang terjadi adalah ruang komnual digunakan sebagai tempat berolahraga pada pagi harinya kemudian digunakan sebagai tempat berjualan kuliner pada sore dan malam hari. Skenario lainnya adalah variasi aktivitas 'duduk' pada ruang tersebut, di mana pengguna dapat lesehan di lantai maupun di tangga.

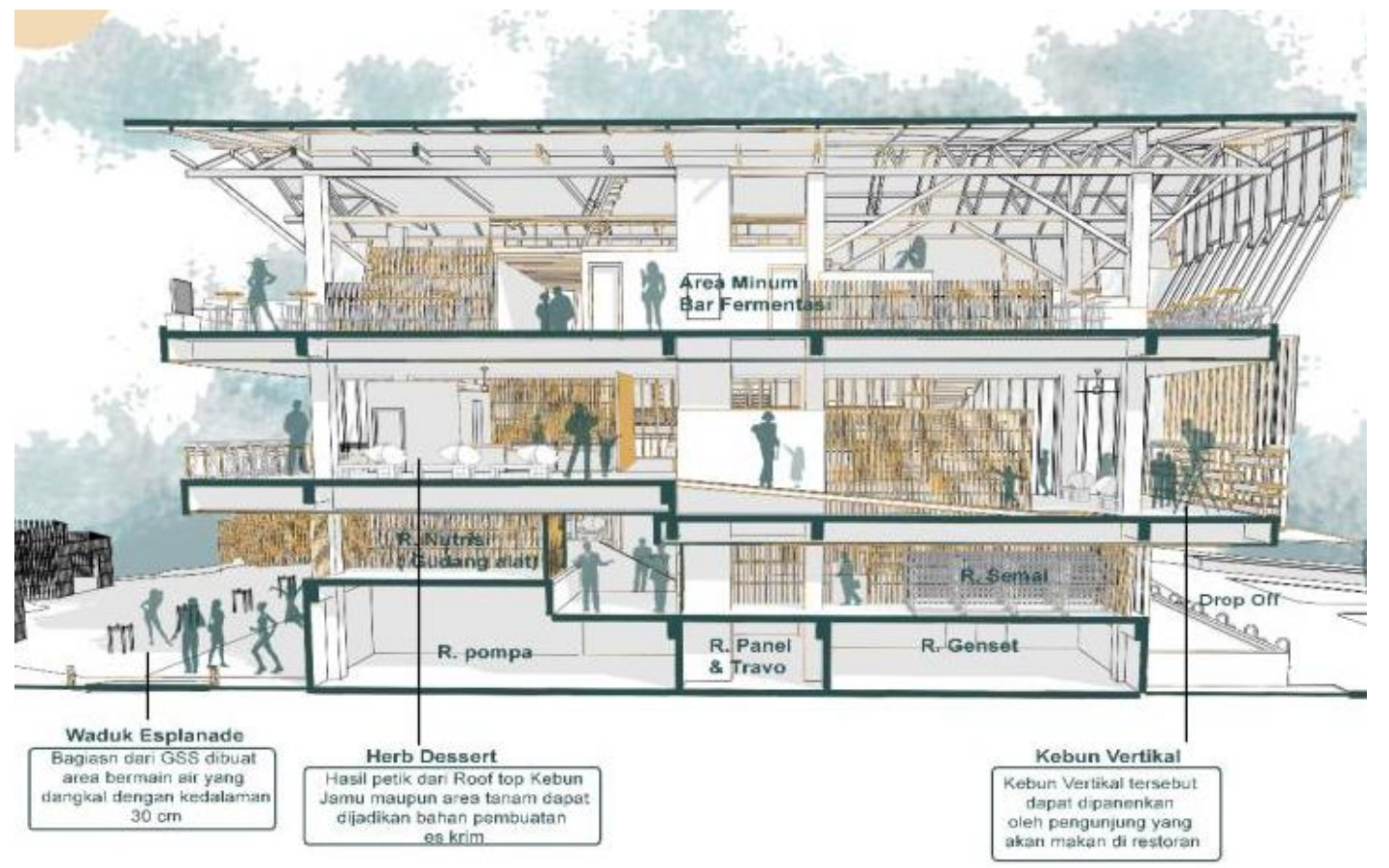

Gambar 8. Potongan perspektif

Sumber: olahan pribadi, 2020 


\section{KESIMPULAN DAN SARAN \\ Kesimpulan}

Dalam merancang suatu tempat ketiga di lingkungan permukiman, dapat menggunakan aktivitas keseharian mereka atau kegiatan yang dilakukan sehari - hari oleh masyarakat sekitarnya sehingga tempat tersebut memiliki karakteristik yang sesuai dengan lingkungan pemukiman yang ada. Karakteristik yang menjadi ciri khas di kawasan Citra 6 terlihat di daerah perairan karena lokasi tersebut digunakan sebagai pusat aktivitas pada pagi dan sore hari. Selain itu daerah perairan di Citra 6 juga menjadi salah satu tempat kuliner bagi masyarakat sekitar. Penggunaan metode berbasis perilaku perlu dibantu dengan metode lainnya seperti space syntax agar peletakan ruang yang diberikan menjadi lebih sosial. Metode space syntax sendiri memerlukan beberapa parameter agar mendapatkan alternatif peletakan ruang yang sesuai dengan kondisi tapak. Penggunaan metode berbasis perilaku menjadi kontekstual dengan konteks tempat ketiga sehingga landasan perancangan menjadi lebih kuat karena menginterpretasikan perilaku keseharian menjadi sebuah ruang. Pojok Hijau juga diperlukan observasi lebih lanjut dengan menggunakan metode arsitektur keseharian. Hal tersebut perlu dilakukan agar variasi aktivitas serta pembentuk ruang menjadi beragam sehingga skenario ruang yang dibentuk menjadi lebih kompleks. Metode ini perlu didukung dengan metode lain agar menjadi landasan yang kuat dalam merancang tempat ketiga.

\section{Saran}

Saran untuk perancangaan metode berbasis perilaku yang lebih lanjut untuk Pojok Hijau yaitu diperlukan observasi kegiatan yang berkelanjutan agar skenario ruang yang terbentuk menjadi lebih variatif. Selain itu, metode space syntax memerlukan parameter yang sesuai dengan kondisi tapak sehingga perancang tidak menggunakan alternatif desain secara prematur. Metode berbasis perilaku memiliki nilai kompleksitas yang lebih apabila lingkup skenario ruang yang dirancang dilakukan secara makro sampai mikro. Untuk data yang lebih baik, diperlukan wawancara dengan warga sekitar kawasan untuk mengetahui detail aktivitas lebih lanjut. Hal lain yang perlu diperhatikan adalah penanda ruang yang dibentuk agar pengguna tidak merasa asing ketika melihat atau menggunakan tanda tersebut.

\section{REFERENSI}

De Certeau, M. (1984). The Practice of Every Day Life. California: University of California Press.

Hillier, B. (1997). Space is the machine (Vol. 18, Issue 3). United Kingdom: Press Syndicate of the University of Cambridge.

Hillier, B., \& Hanson, J. (1988). The social logic of space. United Kingdom: Cambridge University Press.

Jormakka, K., Schurer, O., \& Kuhlmann, D. (2007). Basic Design Method. Berlin: Birkhäuser Basel.

Lefebvre, H. (1991). The Production of Space. United Kingdomg: Wiley-Blackwell.

Nourian, P., Rezvani, S., \& Saryuildiz, S. (2013). Designing with Space Syntax A configurative approach to architectural layout, proposing a computa-tional methodology. Paper presented at Delft, Netherland.

Oldenburg, R. (1989). The Great Good Place. Da Capo Press.

Sutanto, A. (2020). Peta Metode Desain. Jakarta: Universitas Tarumanagara. 
